\title{
The risk of inappropriate timing of complementary foods introduction is increased among first-time mothers and poor households
}

\author{
Puspitorini $^{1}$, Prasetya Lestari ${ }^{2}$, Bunga Astria Paramashanti ${ }^{1}$ \\ ${ }^{1}$ Department of Nutrition, Faculty of Health Sciences, Universitas Alma Ata, Yogyakarta, Indonesia \\ ${ }^{2}$ Department of Midwifery, Faculty of Health Sciences, Universitas Alma Ata, Yogyakarta, Indonesia
}

\begin{abstract}
Background: Global recommendations suggest mothers provide the first complementary food to infants when they reach six months of age. Failure to introduce complementary foods promptly may put infants in adverse health and nutrition outcomes. Objective: This study aimed to analyze factors associated with inappropriate timing of complementary foods introduction in Kebumen Regency. Methods: This study used a cross-sectional design. A multistage cluster sampling was employed to select 355 mothers of children aged 6-23 months in Kebumen Regency. Our dependent variable was the timing of complementary food introduction. Meanwhile, independents variables included factors at the child, parental, and household levels. Univariate and multiple logistic regressions were performed in this study. Results: There was $39.15 \%$ of young children received inappropriate timing of complementary feeding. Being the second-born child or above (OR=0.56; 95\%CI: 0.33-0.95) and coming from high-income households (OR= 0.57; 95\%CI: 0.36-0.90) were protective factors of inappropriate timing of complementary foods introduction. Other variables such as maternal age, maternal education, maternal occupation, father's education, and family support were not significantly associated with incorrect timing of complementary feeding. Conclusions: The proportion of inappropriate timing of complementary foods introduction in Kebumen Regency is alarming and is mainly explained by child's birth rank and household economic status suggesting the importance of targeting nutritional education to first-time mothers as well as poor households.
\end{abstract}

KEYWORDS: complementary food introduction; economic status; first-time mothers; infant and young child feeding

\section{INTRODUCTION}

Globally, World Health Organization (WHO) recommends mothers to breastfeed their infant exclusively in the first six months and to begin complementary feeding when the infant reaches six months of age or 180 days of life while continuing breastfeeding up to two years of age (1). Nonetheless, the exclusive breastfeeding coverage was $40 \%$ in worldwide. Many children were provided with inadequate and unsafe complementary foods in which only $<25 \%$ of infants who consumed diversified foods and were appropriately fed according to their age (2). In Indonesia, the most recent survey of Basic Health Research (Riskesdas) in 2018 revealed that the coverages of early initiation of breastfeeding, exclusive breastfeeding, and dietary diversity were $58.2 \%, 37.3 \%$, and $46.6 \%$, respectively (3).

The introduction of complementary foods at an earlier age was associated with increased risks of food allergies (4-6), overweight and obesity $(7,8)$, and several illnesses $(9,10)$. Meanwhile, the late introduction of complementary feeding was linked to foods acceptance and feeding problems $(10,11)$ and anemia (12). In addition, previous studies showed that both early and late initiation of complementary feeding was associated with childhood stunting (13-15). On the other hand, providing the first food to infants at six months of age

Corresponding author: Bunga Astria Paramashanti, Department of Nutrition, Faculty of Health Sciences, Universitas Alma Ata, Jalan Brawijaya No. 99, Tamantirto, Kasihan, Bantul, Daerah Istimewa Yogyakarta 55183, Indonesia, e-mail: bunga@almaata.ac.id

How to cite: Puspitorini, Lestari P, Paramashanti BA. The risk of inappropriate timing of complementary foods introduction is increased among first-time mothers and poor households. Jurnal Gizi Klinik Indonesia. 2021;17(3):96-102. doi: 10.22146/ijen.53443 
may give benefits to their nutritional fulfillment and development (16).

Several factors have been associated with when to start complementary feeding introduction. Maternal factors that were shown to be the underlying factors included maternal age, educational attainment, perception, and nutritional status $(17,19)$. Other factors that might be related were the child's sex, household income, and nationality $(18,19)$.

To our knowledge, only a few studies were assessing the determinants of early introduction of complementary foods in Indonesia. Those studies took place in Sumatera Selatan (20), Riau (21), Gorontalo (22), and Pontianak (23), however, with limited sample size, study area, variables, or statistical methods. Based on Central Java Health Profile 2017, the proportion of infants aged 0-6 months who were exclusively breastfed in Kebumen was $50.7 \%$ (24) which was far below the national achievement of $61.3 \%$ (25) indicating the existence of infant and young child feeding problems in Kebumen Regency. Therefore, our study aimed to examine the determinants of incorrect timing of complementary feeding among young children in Kebumen Regency.

\section{METHODS}

\section{Study design and participants}

This study used a cross-sectional design which was conducted from February to May 2018 in Kebumen Regency, Central Java Province, Indonesia. We gathered information from 355 mothers regarding their 6-23 months old children data. Mothers of infants and young children acted as the respondents of this study and were asked for their consent. A multistage cluster sampling was used to select our study samples. At the beginning of this study, a list of children under the age of two years old was obtained from three clusters of primary health centres, namely Kebumen I, Kebumen II, and Kebumen III primary health centres. We then randomly picked numbers to choose six villages and selected our study samples proportionally to the village level. Finally, all infants and young children who registered at the posyandu within the villages and met the inclusion criteria of this study were recruited.

\section{Measures}

Complementary feeding introduction. The main outcome in this study was the timing of complementary feeding introduction. Complementary feeding introduction was defined as when infants first received solid, semi-solid or soft foods because the energy and nutrients requirement exceeds what can be fulfilled by exclusive breastfeeding (26). We collected this data based on mothers' recall then categorized it into appropriate timing (at six months) and inappropriate timing (below or above six months) (13).

Independent variables included child's age (6-11 months or 12-23 months), birth order (having first or not first-child), parental age ( $<35$ years or $\geq 35$ years), parental education (high if completed senior high school or low if not completed senior high school), mother's occupation (working or not working), family support, and household economic status.

Family support. Family support was defined as supports given by either husband, mother, or mother in law of our study respondents which comprised four elements of supports (emotional, informational, instrumental, and appraisal) (27) regarding complementary foods. If the family support score was above the mean of family support scores of all participants, we classified it as having the support from families, otherwise not.

Household economic status. Household economic status was determined based on the average of total household monthly income before any deduction (28). We interviewed mothers as our participants and asked them to describe the monthly earnings of the total household members. After that, we compared it with the minimum regional wage which was $1,558,700$ IDR (29). Households with family income less than or equal to the minimum regional wage $(1,558,700$ Indonesian rupiahs (IDR)) were categorized as poor while households with family income more than the minimum regional wage were considered as rich.

We used a structured questionnaire which allowed us to gather data on sociodemographic, timing of complementary foods, and family support aspects. This instrument had been tested for its validation and reliability. This study was ethically approved by the institutional review board of Alma Ata University number $\mathrm{KE} / \mathrm{AA} / \mathrm{IV} / 512 / \mathrm{EC} / 2018$. 


\section{Data analysis}

Descriptive statistics were performed to analyse the distribution of the characteristics of our study samples and respondents and main variables. The association of each dependent variable and the independent variable was tested by univariate logistic regression. All variables with a p-value $<0.25$ in the bivariate analysis entered multiple logistic regression for further analysis. We set a level of significant of 0.05 to determine factors associated with the primary outcome. All of the analyses were done using Stata 14.2 version.

\section{RESULTS}

Table 1 shows that most of the children in our study were aged 12-23 months (61.13\%) and born as the first child $(75.77 \%)$. The majority of mothers and fathers of our study samples were 25-34 years old (62.54\%) and $\geq 35$ years old (48.87\%), respectively. Almost $70 \%$ of mothers completed both junior and senior high schools whereas $46 \%$ of fathers completed senior high school. Approximately seventy-six per cent of mothers were not working while almost half of the fathers worked as in the private sectors. Both poor and rich households shared the same proportion around $50 \%$.

Figure 1 presents the proportion of complementary feeding introduction. There was $39.15 \%$ of young children who had been given complementary foods inappropriately or only $60.85 \%$ of children had been fed their first complementary food exactly at six months old. Furthermore, we examined the determinants of inappropriate timing of complementary foods introduction as shown in Table 2.

In the bivariate analysis, factors associated with incorrect timing of complementary feeding included not being the first-born child (crude $\mathrm{OR}=0.59$; $95 \% \mathrm{CI}$ : $0.35-0.99$ ) and being a child from richer families (crude $\mathrm{OR}=0.52$; 95\%CI: 0.34-0.81). In other words, children who born as the first child were 1.7 times more likely to receive inappropriate timing of complementary food compared to those who born as the second or more. Other variables such as mother's age, mother's education, father's age, and family support were not related to the timing of complementary foods introduction. However, all variables with a p-value $<0.25$ remained included in the multivariate analysis. These variables were birth rank, mother's education, father's education, and household economic status (Table 2).

Table 1. Distribution of characteristics of young children, mothers, and households

\begin{tabular}{lcc}
\hline \multicolumn{1}{c}{ Characteristics } & $\mathbf{n}$ & $\mathbf{\%}$ \\
\hline Age of children (months) & & \\
$\quad 6-11$ & 138 & 38.87 \\
$\quad 12-23$ & 217 & 61.13 \\
Birth rank & & \\
$\quad 1^{\text {st }}$ & 269 & 75.77 \\
$\quad>1^{\text {st }}$ & 86 & 24.23 \\
Age of mothers (years) & & \\
$\quad<35$ & 276 & 77.75 \\
$\quad \geq 35$ & 79 & 22.25 \\
Mother's education & & \\
$\quad$ Low & 203 & 57.18 \\
$\quad$ High & 152 & 42.82 \\
Mother's occupation & & \\
$\quad$ Not working & 271 & 76.34 \\
$\quad$ Working & 84 & 23.66 \\
Age of fathers (years) & & \\
$\quad<35$ & 182 & 51.27 \\
$\quad \geq 35$ & 173 & 48.73 \\
Father's education & & \\
$\quad$ Low \\
$\quad$ High \\
Family support \\
$\quad$ No \\
$\quad$ Yes & 161 & 45.35 \\
Household economic status & 194 & 54.65 \\
$\quad$ Poor & & \\
$\quad$ Rich & 187 & 52.68 \\
$\quad$ & 168 & 47.32 \\
\hline
\end{tabular}

$60.85 \%$

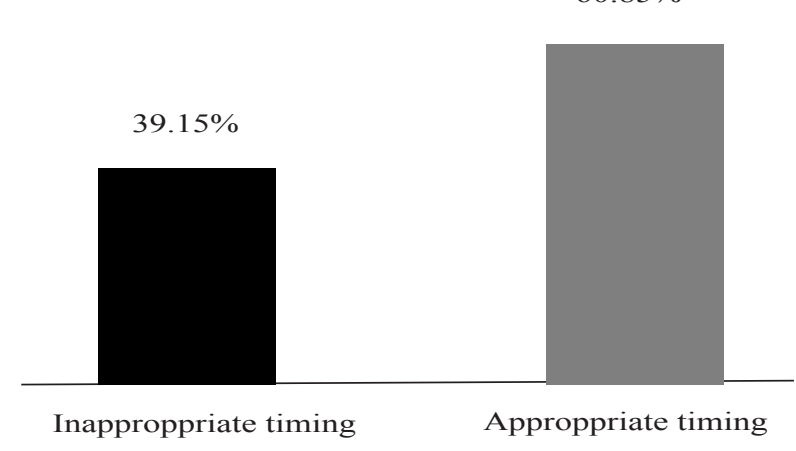

Figure 1. Proportion of complementary feeding introduction 
Puspitorini et al.: The risk of inappropriate timing of complementary foods introduction is increased among first-time mothers and poor households

Table 2. Bivariate and multivariate results of factors associated with inappropriate timing of complementary foods introduction

\begin{tabular}{|c|c|c|c|c|c|c|}
\hline \multirow{2}{*}{ Variables } & \multicolumn{3}{|c|}{ Bivariate analysis } & \multicolumn{3}{|c|}{ Multivariate analysis } \\
\hline & COR & $95 \%$ CI & $\mathbf{p}$ & AOR & $95 \% \mathrm{CI}$ & p \\
\hline \multicolumn{7}{|l|}{ Birth rank } \\
\hline $1^{\text {st }}$ & Ref & & & Ref & & \\
\hline$>1^{\mathrm{st}}$ & 0.59 & $0.35-0.99$ & 0.046 & 0.56 & $0.33-0.95$ & $0.033^{*}$ \\
\hline \multicolumn{7}{|l|}{ Mother's age (years) } \\
\hline$<35$ & Ref & & & & & \\
\hline$\geq 35$ & 0.80 & $0.47-1.34$ & 0.392 & & & \\
\hline \multicolumn{7}{|l|}{ Mother's education } \\
\hline Low & Ref & & & Ref & & \\
\hline High & 0.67 & $0.44-1.04$ & 0.073 & 0.84 & $0.52-1.38$ & 0.494 \\
\hline \multicolumn{7}{|l|}{ Maternal work } \\
\hline Not working & Ref & & & & & \\
\hline Working & 0.84 & $0.50-1.40$ & 0.499 & & & \\
\hline \multicolumn{7}{|l|}{ Father's age (years) } \\
\hline$<35$ & Ref & & & & & \\
\hline$\geq 35$ & 0.90 & $0.59-1.38$ & 0.629 & & & \\
\hline \multicolumn{7}{|l|}{ Father's education } \\
\hline Low & Ref & & & Ref & & \\
\hline High & 0.74 & $0.49-1.14$ & 0.175 & 0.86 & $0.53-1.39$ & 0.536 \\
\hline \multicolumn{7}{|l|}{ Family support } \\
\hline No & Ref & & & & & \\
\hline Yes & 0.82 & $0.53-1.25$ & 0.354 & & & \\
\hline \multicolumn{7}{|c|}{ Household economic status } \\
\hline Low & Ref & & & Ref & & \\
\hline High & 0.52 & $0.34-0.81$ & 0.003 & 0.57 & $0.36-0.90$ & $0.017 *$ \\
\hline
\end{tabular}

${ }^{*} \mathrm{p}<0.05$ = significant; $\mathrm{COR}=$ crude odds ratios; $\mathrm{AOR}=$ adjusted odds ratios; $\mathrm{CI}=$ confidence interval

Multivariate results in the Table 2 showed that children who were born as the first child had twice greater risk to be fed in an inappropriate timing compared to those who were born as the second or more $(\mathrm{p}=0.033)$. Household economic status was also significantly associated with the timing of complementary feeding in which children coming from richer households had a protective effect against inappropriate timing of complementary foods (adjusted $\mathrm{OR}=0.57$; 95\% CI: 0.36-0.90). Conversely, mother's education (adjusted $\mathrm{OR}=0.84 ; 95 \% \mathrm{CI}$ : 0.52-1.38) and father's education (adjusted $\mathrm{OR}=0.86$; 95\%CI: 0.53 1.39) were not significantly associated with the timing of complementary foods introduction.

\section{DISCUSSION}

Young children in this study who were being fed in a timely manner were $60.9 \%$ of the total study population. This proportion was lower compared to studies conducted in the Netherlands (78.6\%) (17), Bangladesh (83.1\%) (30), Ethiopia (83.0\%) (31), and Bhutan (93.0\%) (32), but higher than the study in Saudi Arabia (37.5\%) (18). Although the indicator of timely initiation of complementary feeding had not been specified, the WHO/UNICEF 2018 stated the global target for achieving exclusive breastfeeding to $70 \%$ in 2030 (33). Rationally, if infants in the population reached the global target of exclusive breastfeeding up to six months of age, the proportion of timely introduction of complementary foods will be achieved. This relationship may apply in the other way around.

Incorrect timing of introducing complementary foods was associated with children who were born as the first child. The risk of being fed inappropriately was twice higher than those who were born as the second or more. The result was in line with previous studies conducted 
in Nigeria (34). Being a first-born child or a child from a first-time mother had been associated with the poor understanding of WHO infant and young child feeding guidelines. Mothers who just had their first child tend to be influenced by external factors such as norms and peers as well as by internal factors related to their readiness of responsive feeding, thus preventing them to introduce complementary foods at the appropriate time (35).

Children who were born in high-income families had a lower risk to experience inappropriate timing of complementary foods introduction. The chance was half of those who were coming from low-income households. Previous studies conducted in Saudi Arabia (18) and Brazil (36) confirmed our result. Poor incomes limit the purchasing of health care in term of its accessibility, utility, and the quality of health care (37). It implies that children from poor families may face difficulties in accessing health care facilities and high-quality services such as nutrition counselling and monitoring from qualified health professionals in order to meet infants and young child feeding recommendations. Furthermore, a study among Chinese working women found that maternal return to work due to financial burden increased the risk of stopping breastfeeding below four months of age (38). For this issue, mothers may give breastmilk substitutes in the form of formula milk or solid foods before six months of age. On the contrary, mothers with low economic status may also delay the initiation of complementary foods due to financial restriction to purchase foods (39). Therefore, the low economic status may put infants to receive either early or delayed introduction of complementary foods.

Maternal education was among the factors which did not have a significant relationship with inappropriate timing of introducing complementary foods. Our finding was the opposite of an earlier study conducted among Chinese population in which maternal education was the only significant factor associated with the introduction of complementary food (40). However, high educational attainment does not always represent the desirable knowledge of infant and young child feeding (41). A study in Ethiopia (2019) suggested that maternal birth readiness, registering a child to regular growth checkup, and maternal skill in knowing the specific time to initiate complementary foods was positively associated with appropriate complementary feeding initiation (42). As our study has shown the significant relationship between birth order and timing of complementary foods introduction, we assumed that first-time mothers were more likely unprepared to provide complementary foods in a timely manner.

Our study samples which were obtained from three primary health centres is a strength of this study that allowed us to generalize the results to a wider population representing Kebumen Regency or other areas which have similar settings and characteristics. The topic of this study was among a few studies conducted in Indonesia and was the first study conducted in Kebumen Regency which may give insights to infant and young child feeding practices in Indonesia, thus provide a better understanding in developing nutrition policies and programs. However, this study also had several limitations. A cross-sectional design used in this study restricted us to draw the causeeffect relationship between independent and dependent variables. The use of household income to determine household economic status might have some issues such as inaccurate knowledge of the exact income, not telling the true income, different family members who earned and shared their income, and the variability of income across times.

\section{CONCLUSIONS}

The proportion of inappropriate timing of complementary foods introduction in Kebumen Regency is $61 \%$ and is significantly associated with the child's birth rank and household economic status. For departments of health, NGOs, and community health professionals and workers, this study results suggest the importance of targeting nutritional education to all pregnant women, especially those who are first-time mothers as well as coming from poor households. The program should cover interventions designed to improve maternal preparedness to appropriate complementary feeding practices are needed during and before pregnancy. For future researchers, studies analyzing determinants of complementary feeding practices should carefully consider other influencing factors such as social and cultural aspects. 


\section{Declaration of conflicting interests}

No potential conflict of interest was reported by the authors.

\section{REFERENCES}

1. PAHO/WHO. Guiding principles for complementary feeding of the breastfed child. [series online] 2003 [cited 2019 June 18]. Available from: URL: https://www.who.int/ nutrition/publications/guiding_principles_compfeeding breastfed.pdf

2. World Health Organization (WHO). Infant and young child feeding: key facts. [series online] updated 16 February 2018 [cited 2019 June 18]. Available from: URL: https:// www.who.int/news-room/fact-sheets/detail/infant-andyoung-child-feeding

3. National Institute of Health and Research Development (NIHRD). Laporan nasional Riskesdas 2018. Jakarta: National Institute of Health and Research Development (Balitbangkes); 2019.

4. Caffarelli C, Di Mauro D, Mastrorilli C, Bottau P, Cipriani F, Ricci G. Solid food introduction and the development of food allergies. Nutrients. 2018;10(11):1790. doi: 10.3390/ nu10111790

5. Grimshaw KEC, Maskell J, Oliver EM, Morris RCG, Foote $\mathrm{KD}$, Mills ENC, et al. Introduction of complementary foods and the relationship to food allergy. Pediatrics. 2013;132(6):e1529-38. doi: 10.1542/peds.2012-3692

6. West C. Introduction of complementary foods to infants. Ann Nutr Metab. 2017;70(Suppl 2):47-54. doi: 10.1159/000457928

7. Pluymen LPM, Wijga AH, Gehring U, Koppelman GH, Smit HA, van Rossem L. Early introduction of complementary foods and childhood overweight in breastfed and formula-fed infants in the Netherlands: the PIAMA birth cohort study. Eur J Nutr. 2018;57(5):1985-93. doi: 10.1007/s00394-018-1639-8

8. Wang J, Wu Y, Xiong G, Chao T, Jin Q, Liu R, et al. Introduction of complementary feeding before 4 months of age increases the risk of childhood overweight or obesity: a meta-analysis of prospective cohort studies. Nutr Res. 2016;36(8): 759-70. doi: 10.1016/j.nutres.2016.03.003

9. Rippey PLF, Aravena F, Nyonator JP. Health impacts of early complementary food introduction between formula-fed and breastfed infants. J Pediatr Gastroenterol Nutr. 2020;70(3):375-80. doi: 10.1097/ MPG.0000000000002581

10. Przyrembel H. Timing of introduction of complementary food: short- and long-term health consequences. Ann Nutr Metab. 2012;60(Suppl 2):8-20. doi: 10.1159/000336287
11. Coulthard H, Harris G, Emmett P. Delayed introduction of lumpy foods to children during the complementary feeding period affects child's food acceptance and feeding at 7 years of age. Matern Child Nutr. 2009;5(1):75-85. doi: 10.1111/j.1740-8709.2008.00153.x

12. Wang F, Liu H, Wan Y, Li J, Chen Y, Zheng J, et al. Prolonged exclusive breastfeeding duration is positively associated with risk of anemia in infants aged 12 months. J Nutr. 2016;146(9):1707-13. doi: 10.3945/jn.116.232967

13. Khasanah DP, Hadi H, Paramashanti BA. Waktu pemberian makanan pendamping ASI (MP-ASI) berhubungan dengan kejadian stunting anak usia 6-23 bulan di Kecamatan Sedayu. Jurnal Gizi dan Dietetik Indonesia (Indonesian Journal of Nutrition and Dietetics). 2016:4(2):105-11. doi: 10.21927/ijnd.2016.4(2).105-111

14. Tessema M, Belachew T, Ersino G. Feeding patterns and stunting during early childhood in rural communities of Sidama, South Ethiopia. Pan Afr Med J. 2013;14:75. doi: 10.11604/pamj.2013.14.75.1630

15. Dhami MV, Ogbo FA, Osuagwu UL, Ugboma Z, Agho KE. Stunting and severe stunting among infants in India: the role of delayed introduction of complementary foods and community and household factors. Glob Health Action. 2019;12(1):1638020. doi: 10.1080/16549716.2019.1638020

16. Abeshu MA, Lelisa A, Geleta B. Complementary feeding: review of recommendations, feeding practices, and adequacy of homemade complementary food preparations in developing countries - lessons from Ethiopia. Front Nutr. 2016;3:41. doi: 10.3389/fnut.2016.00041

17. Wang L, van Grieken A, van der Velde LA, Vlasblom E, Beltman M, L'Hoir MP, et al. Factors associated with early introduction of complementary feeding and consumption of non-recommended foods among Dutch infants: the BeeBOFT study. BMC Public Health. 2019;19(1):388. doi: 10.1186/s12889-019-6722-4

18. Alzaheb RA. Factors associated with the early introduction of complementary feeding in Saudi Arabia. Int J Environ Res Public Health. 2016;13(7):702. doi: 10.3390/ ijerph13070702

19. Bournez M, Ksiazek E, Wagner S, Kersuzan C, Tichit C, Gojard S, et al. Factors associated with the introduction of complementary feeding in the French ELFE cohort study. Matern Child Nutr. 2018;14(2): e12536. doi: 10.1111/ men. 12536

20. Heryanto E. Faktor-faktor yang berhubungan dengan pemberian makanan pendamping ASI dini. Jurnal Aisyiah: Jurnal Ilmu Kesehatan. 2017;2(2):141-52. doi: 10.30604/ jika.v2i2.56

21. Aldriana N. Faktor-faktor yang berhubungan dengan pemberian MP-ASI dini di Desa 2 Dayo Wilayah Kerja 
Puskesmas Tandun II Kabupaten Rokan Hulu tahun 2013. Jurnal Maternity and Neonatal. 2015;2(1):1-9.

22. Ibrahim M. Hubungan antara karakteristik ibu dan perilaku ibu dengan riwayat pemberian makanan pendamping ASI (MP-ASI) dini di wilayah Puskemas Atinggola Kecamatan Atinggola Kabupaten Gorontalo Utara tahun 2014. Jurnal Ilmu Kesehatan Masyarakat Unsrat. 2015;5(3):294-301.

23. Wahyuhandani E, Mahmudiono T. Hubungan pengetahuan gizi dan pekerjaan ibu terhadap pemberian MP-ASI dini di Puskesmas Telaga Biru Kota Pontianak tahun 2014. Amerta Nutrition. 2017;1(4):300-7. doi: 10.2473/amnt. v1i4.2017.300-307

24. Department of Health of Central Java. Health profile of Central Java Province 2017. Semarang, Indonesia: Department of Health of Central Java; 2018.

25. Indonesia MoHoRo. Health profile of Indonesia in 2017. Jakarta: Ministry of Health of Republic of Indonesia; 2018.

26. WHO/UNICEF. Global strategy for infant and young child feeding. Geneva, Switzerland: World Health Organization, 2003.

27. Ratnasari D, Paramashanti B, Hadi H, Yugistyowati A, Astiti D, Nurhayati E. Family support and exclusive breastfeeding among Yogyakarta mothers in employment. Asia Pac J Clin Nutr. 2017;26(Suppl 1):S31-5. doi: 10.6133/apjcn.062017.s8

28. International Labour Organization (ILO). Report II: household income and expenditure statistics. Seventeenth International Conference of Labour Statisticians. Geneva: International Labour Organization (ILO); 2003.

29. BPS-Kebumen. Kebumen regency in figures. Kebumen, Indonesia: Central Bureau of Statistics of Kebumen Regency; 2018.

30. Sultana S, Hoque A, Saleh F. Infant and young childfeeding practices and their nutritional status in a national nutrition pro:gramme area in Bangladesh: a cross-sectional study. $\mathrm{J}$ Hum Nutr Food Sci. 2014;2(2):1028.

31. Mohammed S, Getinet T, Solomon S, Jones AD. Prevalence of initiation of complementary feeding at 6 months of age and associated factors among mothers of children aged 6 to 24 months in Addis Ababa, Ethiopia. BMC Nutr. 2018;4:54. doi: 10.1186/s40795-018-0264-5

32. Campbell RK, Kang Y, Keith P, West J. Infant and young child feeding (IYCF) practices and nutritional status under 2 years of age in Bhutan. The FASEB Journal.
2017;31(1): 639.638-639.638. doi: 10.1096/fasebj.31.1_ supplement.639.38

33. WHO/UNICEF. The extension of the 2025 maternal, infant and young child nutrition targets to 2030. Geneva: World Health Organization; 2018.

34. Ogunlesi T, Ayeni V, Adekanmbi A, Fetuga B. Determinants of timely initiation of complementary feeding among children aged 6-24 months in Sagamu, Nigeria. Niger J Clin Pract. 2014;17(6):785-90. doi: 10.4103/1119-3077.144399

35. Walsh A, Kearney L, Dennis N. Factors influencing firsttime mothers' introduction of complementary foods: a qualitative exploration. BMC Public Health. 2015; 15:939. doi: 10.1186/s12889-015-2250-z

36. Dallazen C, Silva SAd, Gonçalves VSS, Nilson EAF, Crispim SP, Lang RMF, et al. Introdução de alimentos não recomendados no primeiro ano de vida e fatores associados em crianças de baixo nível socioeconômico. Cad Saúde Pública. 2018;34(2): e00202816. doi: 10.1590/0102$311 \times 00202816$

37. Adler NE, Newman K. Socioeconomic disparities in health: pathways and policies. Health Aff. 2002;21(2):60-76. doi: 10.1377/hlthaff.21.2.60

38. Chen J, Xin T, Gaoshan J, Li Q, Zou K, Tan S, et al. The association between work related factors and breastfeeding practices among Chinese working mothers: a mixedmethod approach. Int Breastfeed J. 2019;14:28. doi: 10.1186/s13006-019-0223-z

39. Lindsay AC, Machado MT, Sussner KM, Hardwick CK, Peterson KE. Infant-feeding practices and beliefs about complementary feeding among low-income Brazilian mothers: a qualitative study. Food Nutr Bull. 2008;29(1):15-24. doi: 10.1177/156482650802900102

40. Yu C, Binns CW, Lee AH. The early introduction of complementary (solid) foods: a prospective cohort study of infants in Chengdu, China. Nutrients. 2019;11(4):760. doi: 10.3390/nu11040760

41. Paramashanti BA, Hadi H, Gunawan IMA. Timely initiation of breastfeeding is associated with the practice of exclusive breastfeeding in Indonesia. Asia Pac J Clin Nutr. 2016;25(Suppl 1):S52-6. doi: 10.6133/apjen.122016.s11

42. Reda EB, Teferra AS, Gebregziabher MG. Time to initiate complementary feeding and associated factors among mothers with children aged 6-24 months in Tahtay Maichew district, northern Ethiopia. BMC Res Notes. 2019;12(1):17. doi: 10.1186/s13104-019-4061-2 